\title{
Calvert, K. (2015). June Mickle: One Woman's Life in the Foothills and Mountains of
} Western Canada. Calgary: Rocky Mountain Books.

\author{
Reviewed by: Kayla Andrews, MacEwan University
}

Kathy Calvert's book, “June Mickle: One Woman's Life in the Foothills and Mountains of Western Canada", is a biography about a woman living in Alberta in the early 1900's and the role that her hardships and opportunities, in early and late life, played in shaping her into the progressive woman she became. Divided into chapters marked by the biggest turning points in June's life with a seamless transition between each, Calvert's book provides an immersive experience that reads as smoothly as a fictitious novel. Meanwhile, Calvert skillfully avoids inference into June's thoughts and the sacrifice of accuracy as all information is paraphrased from personal diary entries, interviews and images. Calvert's eloquent illustration of June Mickle's life is one that defies conventions and impossible odds; one of strength and resilience in the face of continuous hardship and immeasurable reward. Calvert enlightens the reader to the inspirational story of this Canadian woman, while also placing her life in a broader context of other sociological topics such as family, gender, child development and adaptation. From the struggles of early loneliness, the joys of a life of freedom in rural Canada, and strong family bonds to the opportunities of her later life that caused her to adapt, Calvert exhibits how the multi-talented and endlessly resilient June Mickle carved her existence in the foothills and mountains of western Canada.

As an only child, an unconventional family model at the time, living on an isolated farm, Calvert paints June's early life as one of loneliness, yet held together by close family ties and the 
liberty of rural living. Calvert displays how these aspects, pleasant or not, played a clear role in June's development and values. Having few friends meant she had to amuse herself, with hobbies, that aided her later in life, and farm work reserved for men at the time. It also meant she relied on her family, and as a result grew close family ties, especially with her mother. On a deeper level, Calvert dives into what formed June, her progressiveness, and her adaptability to an everchanging world, as exemplified by events in her early childhood.

Despite being unable to interact with any children her age in her early years, Calvert clearly depicts June as the "innately cheerful" (p. 26) child she was, and this allowed her to preserve and thrive in her environment. June found ways to amuse herself, until she was old enough to work to occupy the days, which came to foster her characteristic "independent spirit and active mind" (p. 23). When old enough, she enthusiastically took on male-dominated jobs around the farm. Calvert's clever display of the interplay between temperament and environment is also illustrated through how, instead of turning to cynicism, June became a compassionate woman who made great sacrifices for her family, defying the stereotype that strong women come with the inevitable side-effect of being cold. June gave to others what she lacked. Calvert showed how June continually chose to expand beyond biology in her own family. She brought in her daughter's friend, for an extended period of time, and later, Calvert remarks, about two friends Don, June's son, brought home from Australia, "In true Mickle tradition, they were immediately adopted and put to work." (p. 275). Calvert emphasizes how June's early life gave June the cheerful, resilient, compassionate and independent personality that carried her, and those she loved, throughout the trials and tribulations of life. 
Despite the isolating aspect, Calvert never missed an opportunity to display June's deep affection for rural living, and horses in particular. Horse-riding and painting, another hobby she nurtured to ease her boredom which later came to be a source of income for her, were two things she continued to do until she physically could not, due to her deteriorating eyesight. June was never bothered by the laborious, never-ending work on the farm. Her rural roots were planted deep, as exemplified by Calvert in June's continuance to live on the rural edge of Alberta, sacrificing the comforts of modern amenities for the comforts of familiarity and freedom. It was only around the age of eighty, for the same reason that she could no longer ride or paint, that she, for the first time in her life, moved to town permanently.

The final shaping factor of June's childhood in Calvert's book was her family ties, especially her close relationship with her mother, Clara. Predictably, June adopted many of her traits. Her mother's strength, compassion, family values and work ethic were apparent in June early on, but later, when June had a family of her own, Calvert made it apparent that June had also learned valuable cooking skills, organization and homemaking skills from her mother. However, they did have their differences, despite their closeness. Calvert remarked that Clara believed in the tradition role of a woman and expressed her fears that June wouldn't be able to get a husband because of her dominant personality and interest in 'male' jobs- that is if June even chose to settle down at all, which was another subject of concern. With this contrast, Calvert also speaks to the gender divide at the time, and the changing attitudes about women over the span of June's lengthy life.

In Calvert's depiction, June's character may have been formed in childhood, but her skills 
continued to grow. Everchanging locations, sources of income, endless hard work and a society in the midst of grand technological change meant June had to be adaptable in her later life as well. It also meant that by the time she had reached old age she had accumulated a plethora of skills. Calvert gives the reader a comprehensive display of June's adaptability, touching on many of the skills she mastered. Horse riding and painting were skills she had carried from her youth, that she continued to utilize and later mastered. However, some were entirely new, and most came from the outfitting business the Mickle family took on.

Running an outfit in the mountains, near Lake Louise, meant June had to learn to ski and run a skidoo in her forties, a feat that was not easy but doable- and June proved so. Although her sense of business and organization were already strong, she strengthened them more so and became efficient at running the outfit. Meanwhile, Calvert is careful not to undermine her compassion, organization and calm demeanor, which held the family together through hard times and pushed them forwards in the face of opportunity. Calvert provided a good summary of June in context of running the outfit: "It was her business sense that kept them solvent and even successful. She also knew she held the family together and provided the direction they needed." (p. 178). The risk of taking on the outfit, and the chain of multiple other businesses in the same time period, and the later success of it is one of Calvert's greatest examples of June's adaptability and her progressive nature as she became the dominant leader of the family during this time of hard work but great reward.

Calvert successfully achieves two goals with her biography of June Mickle's long and colorful life. Firstly, Calvert enlightens many on June's extraordinary story which, without her 
effort and the forthcoming nature of June and her family, would have been relatively unknown. June Mickle was born into a vastly patriarchal world where the accomplishments of a woman were ignored, if even acknowledged in the first place and Calvert provides one of the few - if not the only- narrative on June and her family. Calvert also offers a deeper commentary on many sociological topics, specifically pertaining to family structure and gender norms, and the effects of life events, hardships and opportunities on the development and later adaptation of children, without detracting from the narrative. Calvert accomplishes this by offering an accurate and detailed account of June's life while also subtly bringing to focus the underlying sociological themes.

Calvert's book can be appealing to readers of many demographics. Anyone studying sociology, family, child development or changing gender roles would benefit from her book. I believe it would also be an effective anecdote for post-secondary students studying the above topics. Calvert's book has a broad readership as it touches on many issues in the legacy of this Canadian woman transcending conventions and borders in early and late $20^{\text {th }}$ century Canada.

Calvert not only illustrates the life of June Mickle, but also provides an insightful narrative to deeper matters of family, gender and how life events form people and push them to adapt. Her book, while it could be read for recreation alone, is educational in regard to a variety of fields and interests beyond those of the sociological discipline; such as psychology or history. I enjoyed that Calvert was able to indirectly add undertones of deeper topics relevant both then and today in the modern world, without sacrificing the accuracy or taking away from June's story. I would recommend this book to anyone, especially those interested in family and child development. 